\title{
STUDI EKSPERIMEN PENGGUNAAN PARTICIPATORY PHOTOGRAPHY UNTUK MENINGKATKAN DETERMINASI DIRI INDIVIDU TULI
}

\author{
Benedicta Herlina Widiastuti \\ bherlinawidiastuti@gmail.com \\ Fakultas Psikologi Universitas Sanata Dharma Yogyakarta
}

\begin{abstract}
Abstrak
Program pelatihan bagi individu berkebutuhan khusus (IBK) sudah menawarkan banyak ketrampilan tetapi belum dapat menjawab kebutuhan IBK untuk hidup mandiri. Hal ini berarti ada faktor yang dibutuhkan IBK yang tidak dapat dijawab dengan pemberian ketrampilan. Faktor tersebut dirumuskan dalam penelitian ini sebagai determinasi diri. Determinasi diri adalah kualitas yang harus dimiliki individu untuk dapat mengarahkan seluruh kemampuan dan tindakan bagi pemenuhan tujuan hidupnya. Penelitian ini bertujuan untuk membuktikan ketepatan metode participatory photography dalam meningkatkan determinasi diri IBK. Subyek terdiri dari 21 siswa SLB Tunarungu. Partisipan menggunakan kamera untuk mengambil gambar dengan tema cita-cita. Gambar yang diambil beserta ceritanya dibagikan kepada kelompok. Pada akhir eksperimen diadakan pameran untuk membagikan hasil foto kepada masyarakat luar. Pre test dan post test dilakukan untuk mengukur determinasi diri. Analisa foto dan wawancara dilakukan untuk mengumpulkan data kualitatif. Berdasar analisa tematik data kualitatif, metode ini terbukti meletakkan dasar yang kuat bagi determinasi diri IBK. Subyek merasakan pengalaman memilih dan mengkomunikasikan pilihannya lewat foto yang mereka bagikan sehingga mereka merasa keinginannya dihargai dan didengarkan. Pengalaman ini adalah faktor pembentuk determinasi diri. Hasil uji beda ( $t$-test) menunjukkan tidak ada perbedaan signifikan pada determinasi diri. Hasil ini disebabkan oleh adanya dekonstruksi determinasi diri pada beberapa subyek. Dekonstruksi ini karena keinginan subyek yang bertentangan dengan keinginan significant others di sekitar subyek.

Kata kunci: Determinasi diri, Participatory photography
\end{abstract}

\begin{abstract}
Training programs for special needs individuals offered many skils but yet to answer the need of the special needs to be self-supporting. This means there are factors that can't be answered by skills trainings, it is formulated in this study as self-determination. Self determination is the quality an individu has to direct one's capability and actions to aim one's purpose. This study examined the use of participatory photography to increasse self-determination. Subjects are 21 deaf students. The participants utilized camera to take pictures of their aspiration. The pictures and the stories behind are shared to the participants' group. Exposition is held by the end of this experiment to share the pictures taken to the society. Pre test and post test are taken to measure the self-determination. Pictures analysis and personal interview are done to collect the qualitative data. Thematic analysis showed that this method laid a strong fondation for special needs individuals' self-determination. Subjects experienced chosing, discerning, and communicating their options through pictures that they shared. Doing so, they experienced their aspirations heard and respected. These experience are factors for self-determination. $T$ test showed that no significance difference in self-determination. This was the effect of selfdetermiination deconstruction in some of the participants. It happened because the aspiration of the participants is contrary to the aspirations of their significant others.
\end{abstract}


Keywords: Self-determination, Participatory photography

\section{Pendahuluan}

Individu Berkebutuhan Khusus (IBK) adalah kelompok besar orang yang memiliki keterbatasan, gangguan mental serius, dan kelompok minoritas. Ada beberapa penggolongan anak berkebutuhan khusus yaitu didasarkan pada kebutuhan atau hambatan yang disandangnya, seperti anak dengan hambatan komunikasi interaksi dan bahasa (HKIB), anak dengan hambatan persepsi, motorik dan mobilitas (HPMM), anak dengan hambatan emosi \& perilaku (HEP), anak dengan hambatan kecerdasan \& akademik (HKA), dan anak dengan bakat istimewa \& cerdas istimewa (Hermanto, 2010)

Penggunaan kata cacat pada lembagalembaga resmi seperti "Yayasan Pembinaan Anak Cacat" menunjukkan cara pandang yang masih menganggap bahwa kebutuhan khusus adalah kekurangan dan ketidaknormalan. Begitu pula sebaliknya, para IBK kerap merasa minder dan sering mengatakan "saya tidak bisa" dalam melakukan sesuatu. Apa yang diungkapkan oleh IBK tersebut bukan hanya sekedar menyatakan ketidakmampuan. Lebih dari itu, nampak adanya kesan tidak berdaya yang dimiliki oleh IBK. Misalnya saja pada suatu hari di pusat pelatihan, seorang IBK yang baru saja menyelesaikan pelatihan memasak menyatakan bahwa sesudah pelatihan ini ia akan pulang ke kampungnya dan tidak akan menggunakan keahlian barunya karena dia merasa tidak mampu menggunakannya. Dia bisa memasak bermacam menu yang luar biasa karena pelatihan itu, tetapi dia tidak merasa akan dapat menggunakan keahliannya itu untuk mencari nafkah dan mengubah hidupnya. Dia merasa tidak akan bisa menjual hasil kreasinya ataupun menjual keahliannya. "Saya tidak bisa, itu saja" katanya. (wawancara informal dengan IBK, Januari 2011, di YAKKUM Yogyakarta). Dari contoh tersebut dapat disimpulkan bahwa "IBK telah dan sampai sekarang terus menjadi orang-orang yang paling terampas haknya dan paling tidak berdaya" (White, 2005).

Menurut Kamus Besar Bahasa Indonesia, daya adalah kemampuan melakukan sesuatu atau kemampuan bertindak (KBBI, 2011). Dengan demikian, tidak berdaya dapat dipahami sebagai ketidakmampuan melakukan sesuatu atau ketidakmampuan bertindak. Ketidakberdayaan yang dipelajari (learned helplessness) adalah suatu keyakinan bahwa seseorang tidak mampu menghentikan atau melarikan diri dari situasi buruk dan mencoba menggeneralisasikan pada situasi lain. (Hergenhahn \& Olson, 1997).

Oleh sebab itu, pemberdayaan, proses perubahan dari situasi tidak berdaya menjadi berdaya, menjadi sebuah keharusan bagi setiap warga masyarakat. Determinasi diri dan pemberdayaan harus menjadi kata kunci di antara mereka yang bekerja dengan IBK (Sprague, 2000). Karena orang-orang yang berdaya dapat mengambil bagian secara aktif meningkatkan kesejahteraan hidupnya, mendukung keluarga dan lingkungannya menjadi lebih baik, dan memimpin perubahan bagi komunitasnya (National Prevention Strategy, 2011). Mereka juga lebih inovatif, mampu memberi pengaruh yang baik dan inspirasional (Spreitzer, et al. 1999).

Sedangkan memberdayakan seseorang hanya mungkin jika determinasi dirinya terfasilitasi. Proses pemberdayaan harus berawal dari pengungkapan tujuan personal. Tujuan yang bermakna secara personal akan mampu mendorong individu untuk melampaui tantangan. Hal inilah yang selama ini luput dari perhatian, tujuan yang bermakna bagi IBK itu sendiri. Perilaku yang digerakkan oleh tujuan yang bermakna bagi individu yang bersangkutan akan bersifat autonomous karena dia percaya bahwa tujuannya cukup berharga untuk melewati banyak hambatan (Cattaneo, 2010). Tujuan dan tindakan yang 
bersifat autonomous inilah yang didefinisikan sebagai determinasi diri.

Determinasi diri adalah kemampuan untuk mengambil tindakan yang didasari oleh kehendak yang memungkinkan seseorang bertindak sebagai agen utama dalam hidupnya dan untuk memelihara atau mengembangkan kualitas hidupnya (Wehmeyer, 2008). Kemampuan ini mensyaratkan adanya kekuatan (power) untuk membuat suatu perubahan. Secara sederhana, perubahan dapat berbentuk seperti tujuan, cita-cita, atau impian. Namun, semuanya itu membutuhkan keinginan dari dalam dirinya sendiri. Keinginan yang mempunyai kekuatan untuk membuat suatu perubahan sering dipahami sebagai motivasi. Motivasi dapat berasal dari dalam diri maupun dari perjumpaan dengan pengalaman di luar diri. Meskipun motivasi tersebut bisa dipengaruhi oleh hal di luar diri, idealnya para IBK harus dapat mengklaimnya sebagai milik sendiri.

Determinasi diri tersusun dari beberapa aspek, yaitu pengetahuan akan adanya pilihan, pembuatan keputusan dan pencapaian tujuan. Selain ketiga aspek tersebut, individu juga harus memperjuangkan keputusan mereka dan belajar dari hasil perjuangan dan pengalaman. (Trainor 2005). Orientasi otonomi dalam individu adalah indikator positif determinasi diri dan menunjukkan kecenderungan perilaku yang mengarah pada minat personal yang utama dan nilai yang terintegrasi serta pengalaman hakiki dalam memilih sebuah tindakan (Lewis \& Neighbors, 2005).

Faktor yang mempengaruhi determinasi diri adalah pengalaman individu akan kemampuan menjalankan aktivitas harian, kebebasan mengungkapkan emosi dan pendapat, kemampuan mengkomunikasikan pilihan dan keinginan personal, kemampuan sosial dasar dan kemampuan berinteraksi dengan orang sekitar (Nota et al., 2007) Pengalaman individu dalam mengkomunikasikan keinginannya adalah faktor yang kami upayakan dalam penelitian ini. Pengalaman mengartikulasikan harapan ini yang tidak banyak terlihat pada penanganan bagi IBK selama ini.

Determinasi diri adalah kemampuan untuk melakukan tindakan yang didasari oleh kehendak yang memungkinkan seseorang bertindak sebagai agen utama dalam hidupnya dan untuk memelihara atau mengembangkan kualitas hidupnya (Wehmeyer, 2008). Orang yang mempunyai determinasi diri bertindak atas dasar pilihan dan keinginan sendiri dan bukan atas dasar paksaan. Determinasi diri juga mensyaratkan bahwa pilihan tersebut dibuat atas dasar kesadaran pilihan dan intensi yang disadari (Wehmeyer, 2008). Determinasi diri (motivasi intrinsik) menghasilkan sense of personal control yang merupakan tolok ukur keberhasilan seseorang keluar dari ketidakberdayaannya. Keberhasilan tersebut karena peningkatan power yang dicapai oleh individu tersebut karena usahanya sendiri (Cattaneo, 2005)

Determinasi diri artinya seorang individu mempunyai pilihan, entah dilaksanakan dengan mempunyai kontrol atau ketika memilih untuk tidak mempunyai kontrol atas hasil. (Deci \& Ryan, 1985) Seseorang dianggap sejahtera (well being state) secara individual jika: dia mempunyai determinasi diri (Nelson, 2005) Pemberdayaan psikologis meliputi komponen intrapersonal, ekstrapersonal dan perilaku. Komponen intrapersonal adalah keyakinan yang mengacu pada "bagaimana orang berpikir tentang dirinya sendiri" dan termasuk juga motivasi (Cattaneo, 2005)

Metode participatory photography memberikan jalan bagi IBK untuk mempunyai pengalaman ini. Pengalaman mengekspresikan pandangan mereka akan dunia, bagaimana mereka melihat dunia dan apa yang ada dalam dunia mereka. Melalui metode ini, para IBK akan diajak untuk berpartisipasi aktif dalam memotret gambar (participatory photography) yang menjawab beberapa pertanyaan yang 
didesain untuk memperlihatkan cita-cita atau keinginan mereka.

Metode ini dibagi menjadi 2 bagian (1) pengambilan foto oleh subyek yang menunjukkan keinginan subyek (2) penceritaan foto yang diambil kepada kelompok. Pengambilan foto ini mendukung kemampuan individu untuk mengekspresikan keinginannya yang merupakan faktor pendukung dalam pembentukan determinasi diri dan aspek pertama dan kedua determinasi diri yaitu pengetahuan akan pilihan dan kemampuan mengambil keputusan atas pilihan yang ada. Hal ini berarti penggunaan metode ini dapat meningkatkan determinasi diri. Metode ini telah coba dilakukan terhadap kelompok marginal lain yang tidak mampu berpartisipasi dalam masyarakat karena perbedaan tingkat power (kekuasaan), seperti pada perempuan Africa America (Chung dkk, 2009), dan pada anak-anak usia 8-12.

Tetapi metode ini baru digunakan untuk menjembatani komunikasi antara 2 pihak yang berbeda tingkat kekuasaannya dan tidak pernah diukur secara empiris akibatnya pada individu itu sendiri. Penelitian selama ini hanya ada pada tataran dampaknya dalam komunikasi pihak-pihak terkait. Maka penelitian ini ingin mengetahui apakah penggunaan metode ini dapat memberi akibat positif pada individu yang melakukannya. Dalam hal ini, dampak positifnya adalah peningkatan determinasi diri IBK.

\section{Participatory photography} adalah metode yang menggunakan foto yang diambil sendiri oleh subyek (partisipan) sebagai jalan untuk mengungkap dan mengerti dunia sebagaimana subyek penelitian melihatnya. Subyek diajak untuk mengambil foto yang menggambarkan situasi hidup mereka pada tema tertentu dan lalu mendiskusikannya dalam kelompok dengan metode refleksi kritis.

Stage pengambilan foto dan story telling meliputi: pengambilan foto, menggunakan foto untuk menjawab pertanyaan, dan berdialog dengan teman sebaya. Story telling dilaksanakan mingguan dengan cara: subyek membagikan foto mereka dan sebagai grup mereka merefleksikan dan membagikan arti foto mereka. Strategi yang dipilih mempunyai tujuan untuk membangkitkan kemampuan "bersuara" dan mendukung refleksi kritis lewat dialog grup (FosterFishman dkk, 2010) Metode yang sama telah digunakan untuk menjembatani komunikasi antara para pengungsi di Kanada dan petugas sosial yang menangani anak mereka (Dumbrill, 2009) dan meningkatkan collective efficacy didalam kelompok orang Afrika Amerika yang mengalami depresi (Chung dkk, 2009)

Individu berkebutuhan khusus lebih dikenal dalam masyarakat sebagai penyandang cacat. Cacat artinya kekurangan yang menyebabkan nilai atau mutunya kurang baik atau kurang sempurna, tidak sempurna (KBBI, 2011). Penelitian ini mengambil subyek IBK tuna rungu. Tuna rungu artinya tidak dapat mendengar. Biasanya karena tidak dapat mendengar mereka juga mempunyai kesulitan berbahasa lisan atau tuna wicara. Tuna wicara artinya bisu, tidak dapat berbicara (KBBI, 2011). Mereka biasanya saling berkomunikasi secara lisan dengan cara membaca gerak bibir dan bahasa isyarat.

Telah diungkapkan di depan bahwa proses perubahan dari situasi tidak berdaya menjadi berdaya harus berawal dari pengungkapan tujuan yang bermakna bagi individu yang bersangkutan atau bila dilihat dari sisi lain adalah aspek pertama determinasi diri. Participatory photography memberikan kesempatan bagi subyek untuk mendapatkan pengalaman positif dalam rangka pengkomunikasian keinginan subyek. Oleh karena itu, metode participatory photography ini dapat secara efektif mengungkap cara pandang dan harapan subyek/ partisipan maka kami menduga bahwa metode ini dapat secara signifikan meningkatkan determinasi diri subyek. 


\section{Metode Penelitian}

\section{Subjek penelitian}

Subjek di dalam penelitian ini berjumlah 21 orang yang dibagi dalam dua kelompok yaitu kelompok eksperimen dan kelompok kontrol. Kelompok eksperimen terdiri dari 11 orang dan kelompok kontrol terdiri dari 10 orang. Kisaran umur subjek adalah 10-17 tahun. Ketika pretest terdapat 30 subyek tetapi karena kehadiran yang tidak memenuhi syarat, maka terdapat 9 subyek yang digugurkan datanya. Sehingga tersisa 21 subyek. Subjek dalam penelitian ini adalah murid-murid dari dua SLB-B yang berbeda tetapi dari kelompok umur dan kelas yang sama yang berada di Yogyakarta.

\section{Jenis penelitian}

Penelitian adalah penelitian eksperimen nonrandomized pretest posttest control group design yang berparadigma kuantitatif. Eksperimen digunakan untuk melihat pengaruh metode participatory photography pada determinasi diri IBK.

Tabel 1. Desain eksperimen (Pre test-post test Control Group Desain)

\begin{tabular}{|l|l|l|l|}
\hline KE & T1 & $\mathrm{X}$ & $\mathrm{T} 2$ \\
\hline KK & T1 & $-\mathrm{X}$ & $\mathrm{T} 2$ \\
\hline
\end{tabular}

Keterangan:

KE : Kelompok Eksperimen

KK : Kelompok Kontrol

T1 : Pre test

T2 : Post test

$\mathrm{X}$ : Pemberian Perlakuan

-X : Tanpa Perlakuan

\section{Alat Ukur Penelitian}

Alat ukur determinasi diri yang digunakan adalah Arc's self determination scale adolescent version (Wehmeyer, 1995). Alat ukur ini diperuntukkan bagi remaja dengan kebutuhan khusus. Skala ini mempunyai 72 item dan terdiri dari empat bagian. Setiap bagian mengukur satu karakteristik determinasi diri yaitu: otonomi, regulasi diri, psychological empowerment, dan self-realization. Aitem bagian satu berisi pernyataan dan diisi menurut empat tingkat kesesuaian. Bagian dua dan bagian empat berisi keadaan awal dan subyek mengisi rencana agar keadaan akhir atau tujuan tercapai. Setiap aitem di bagian tiga terdiri berisi dua pernyataan, subyek memilih yang lebih sesuai untuknya. Koefisien alpha untuk reliabilitas keseluruhan adalah 0,90.

\section{Prosedur Penelitian}

Metode eksperimen yang digunakan dalam penelitian ini adalah participatory photography. Subyek mengambil foto yang menjawab pertanyaan yang diberikan oleh peneliti. Pertanyaan yang diberikan adalah pertanyaan yang berhubungan dengan citacita subjek, yaitu: (1) apa cita-citamu? (2) apa yang harus kamu lakukan untuk mencapai cita-citamu? (3) apa kesulitan yang kamu hadapi untuk mencapai citacitamu? dan (4) apa kesulitanmu sebagai tuna rungu? Lalu foto yang diambil oleh subjek digunakan sebagai media untuk bercerita. Subjek bercerita mengenai foto yang diambilnya dan apa makna foto itu bagi subyek. Selama eksperimen berlangsung, subjek dibekali dengan kamera disposable untuk mengambil foto. Eksperimen berlangsung selama dua bulan dari bulan Maret 2013 hingga April 2013. Setiap pertanyaan diberi waktu seminggu untuk pengambilan foto. Pengambilan foto dapat dilakukan di mana pun subyek menemukan benda atau hal atau kegiatan yang dapat mewakili cita-citanya. Setelah semua pertanyaan terjawab diadakan pameran hasil foto IBK untuk membuka suara mereka bagi orang di luar kelompok mereka

\section{Hasil Penelitian}

\section{Deskripsi Hasil Penelitian}

Pada penelitian ini sebenarnya terdapat 30 subyek penelitian, namun pada pelaksanaannya 9 subyek gugur karena tidak mengikuti post test sehingga tersisa 
21 subyek. Data deskriptif hasil penelitian dapat dilihat di tabel 2

Tabel 2. Hasil pretest dan postest kelompok eksperimen

\begin{tabular}{|c|c|c|}
\hline Subyek & Pre test & Post test \\
\hline 1 & 106.0 & 107.0 \\
\hline 2 & 92.0 & 73.0 \\
\hline 3 & 77.0 & 97.0 \\
\hline 4 & 82.0 & 77.0 \\
\hline 5 & 92.0 & 87.0 \\
\hline 6 & 85.0 & 87.0 \\
\hline 7 & 102.0 & 115.0 \\
\hline 8 & 91.0 & 96.0 \\
\hline 9 & 86.0 & 106.0 \\
\hline 10 & 76.0 & 64.0 \\
\hline 11 & 94.0 & 82.0 \\
\hline
\end{tabular}

subyek mengalami penurunan skor determinasi diri.

Tabel 3. Deskripsi Hasil Penelitian

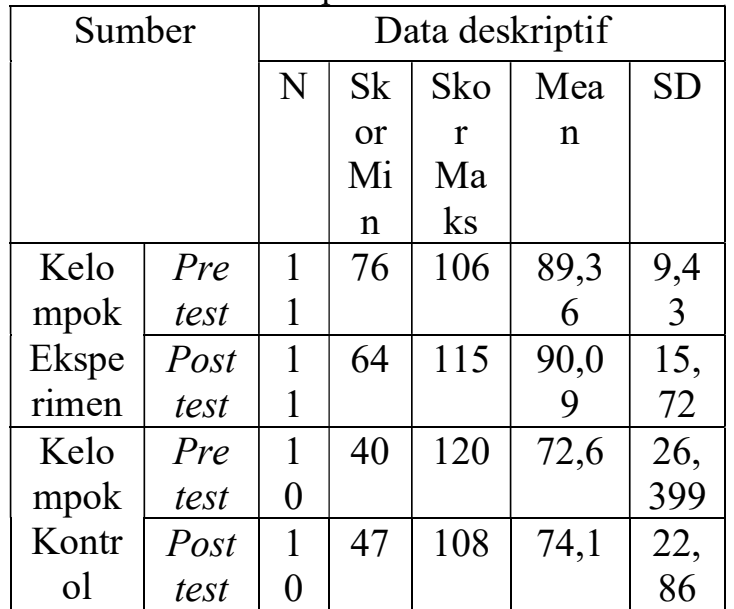

Tabel 2. menunjukkan bahwa terdapat enam subyek (55\%) yang mengalami peningkatan skor dan lima

Tabel 4. Uji normalitas

\begin{tabular}{|c|l|c|c|c|c|}
\hline \multicolumn{2}{|c|}{ Sumber } & \multicolumn{3}{c|}{ Uji normalitas Kolmogorov-Smirnov } \\
\cline { 3 - 6 } \multicolumn{2}{|c|}{} & $\mathrm{N}$ & $\begin{array}{c}\text { Skor } \\
\text { normalitas }\end{array}$ & $\begin{array}{c}\text { Signifika } \\
\text { nsi }\end{array}$ & Hasil \\
\hline \multirow{2}{*}{ Kelompok eksprimen } & Pre test & 11 & 0.176 & 0,200 & Normal \\
\cline { 2 - 6 } & Post test & 11 & 0,123 & 0,200 & Normal \\
\hline \multirow{2}{*}{ Kelompok kontrol } & Pre test & 10 & 0,159 & 0,200 & Normal \\
\cline { 2 - 6 } & Post test & 10 & 0,186 & 0,200 & Normal \\
\hline
\end{tabular}

Hasil dari tabel 4. memperlihatkan bahwa seluruh persebaran data normal

Tabel 5. Uji homogenitas

\begin{tabular}{|l|c|c|c|c|c|}
\hline \multicolumn{2}{|c|}{ Sumber } & \multicolumn{4}{c|}{ Uji homogenitas } \\
\cline { 3 - 6 } \multicolumn{2}{|c|}{} & $\mathrm{N}$ & $\begin{array}{c}\text { Skor } \\
\text { homogenitas }\end{array}$ & Signifikansi & Hasil \\
\hline $\begin{array}{l}\text { Kelompok } \\
\text { eksprimen }\end{array}$ & Pre test & 11 & 0.176 & 0,200 & Normal \\
\cline { 2 - 6 } & Post test & 11 & 0,123 & 0,200 & Normal \\
\hline $\begin{array}{l}\text { Kelompok } \\
\text { kontrol }\end{array}$ & Pre test & 10 & 0,159 & 0,200 & Normal \\
\cline { 2 - 6 } & Post test & 10 & 0,186 & 0,200 & Normal \\
\hline
\end{tabular}

Tabel 5 menunjukkan data berasal dari populasi yang homogen.

\section{Hasil Uji Hipotesis}

Berdasarkan penelitian di atas dilakukan uji beda dengan menggunakan $t$ test. Berikut adalah hasil uji perbedaan tersebut

$$
t(19)=0,136, p=0,893(p>0,05)
$$

sehingga hipotesis ditolak
Hasil uji beda determinasi diri kelompok eksperimen dan kelompok kontrol menunjukkan tidak ada perbedaan signifikan antara kelompok kontrol dan kelompok eksperimen. 


\section{Pembahasan}

Subyek yang mempunyai perasaan positif pada proses mengalami peningkatan determinasi diri. 55\% subyek mengalami kenaikan skor determinasi diri, $45 \%$ mengalami penurunan. Meskipun lebih banyak subyek yang mengalami kenaikan skor determinasi diri, uji t tidak dapat menemukan dampak yang terukur dalam peningkatan determinasi diri. Penurunan ini kami duga disebabkan oleh pengaruh lingkungan yang sangat penting bagi pembentukan determinasi diri IBK di budaya Indonesia. Subyek yang ingin membangun sendiri cita-citanya dihalangi oleh lingkungan yang tidak mendukung dan bahkan menentang keinginannya.

Dekonstruksi determinasi diri terjadi pada saat-saat krusial ketika subyek didorong untuk mencari, menentukan, dan merencanakan cita-citanya. Subyek yang ingin membangun cita-cita diberi respon negatif oleh significant others-nya. Beberapa subyek bahkan ditentang menginginkan cita-citanya kemudian diminta untuk mempunyai cita-cita lain. Pengalaman ini membuat subyek tersebut merasa semakin tidak berdaya dalam mengontrol hidupnya sehingga terjadi dekonstruksi determinasi diri.

Meskipun tidak terdapat peningkatan yang signifikan secara kuantitatif, Secara kualitatif metode participatory photography memberikan banyak dampak positif bagi subyek. Metode participatory photography memberikan perasaan positif pada subyek karena merasa keberadaan dirinya dihargai. Subyek merasa didengarkan, mampu berprestasi, dan dihargai suaranya. Hal ini terlihat dari hasil wawancara dengan subyek. Subyek merasa bangga karena mampu berkarya dan orang lain menghargai karyanya. Kemampuan subyek dalam mengkomunikasikan pendapat juga meningkat.

Metode ini memberikan jalan bagi IBK untuk mempunyai pengalaman yang berdampak positif bagi diri IBK. Metode ini menyediakan kesempatan bagi IBK untuk membuat pilihan, mengkomunikasikan keinginan, dan mengekspresikan pandangan mereka akan dunia. Metode ini juga membantu orang di luar IBK melihat bagaimana IBK melihat dunia dan apa yang ada dalam dunia mereka. Metode ini tidak hanya meningkatkan kemampuan IBK mengkomunikasikan keinginan saja. Metode ini juga memberi IBK kebebasan mengungkapkan emosi dan pendapat, meningkatkan kemampuan mengkomunikasikan pilihan personal, meningkatkan kemampuan sosial dasar dan kemampuan berinteraksi dengan orang sekitar.

Metode participatory photography dilaksanakan dengan urutan: (1) subyek mengambil foto yang menjawab pertanyaan ekperimen lalu (2) menceritakan foto hasil karyanya dalam sesi story telling. Pada tahap pengambilan foto, subyek merasakan pengalaman memilih. Subyek memilih inti jawaban atas pertanyaan eksperimen. Subyek, berdasar pokok jawaban itu, memilih obyek foto beserta alasannya. Subyek kemudian menceritakan alasan foto tersebut diambil, arti foto tersebut untuk subyek, dan bagaimana foto tersebut diambil.

Pertanyaan eksperimen adalah (1) apa cita-citamu? (2) apa yang harus kamu lakukan untuk mencapai cita-citamu? (3) apa kesulitanmu untuk mencapai cita-cita? (4) apa kesulitan yang kamu hadapi sebagai tuna rungu? Pada pertanyaan pertama subyek merasakan pengalaman memilih satu dari bermacam profesi yang dia tahu. Pada pertanyaan kedua subyek menentukan tindakan yang ingin dia kerjakan demi tujuannya. Pertanyaan ketiga menghantar subyek untuk meramalkan kesulitan yang akan dia hadapi. Pertanyaan keempat membuat subyek berefleksi tentang kehidupannya dan menemukan hal yang menghambatnya. Hal ini menyebabkan subyek sadar akan kesulitan sehingga memberi subyek kesempatan untuk memikirkan bagaimana dia akan menghadapinya. Subyek jarang mempunyai kesempatan untuk membuat pilihan semacam ini. 
Tindakan memilih memberi subyek pengalaman untuk berkomunikasi dengan dunia. Subyek mengungkapkan keinginan dan mengekspresikan pandangan mereka akan dunia. Orang di sekitar subyek dapat melihat bagaimana subyek melihat dunia dan apa yang ada dalam dunia subyek. Subyek merasa positif terhadap proses ini karena keinginan, pengalaman, dan pikirannya didengarkan. Hal ini terutama terlihat pada sesi pameran fotografi, ketika foto IBK dipamerkan kepada masyarakat luas.

Ketika pertanyaan pertama dilontarkan, foto yang mereka hasilkan bertema tempat, alat, atau hasil karya yang menggambarkan cita-cita. Foto yang bertema tempat adalah foto universitas, toko, galeri, dan bengkel. Foto yang bertema alat adalah mesin, motor, dan kamera. Foto yang bertema hasil karya adalah kue tart, kanopi, dan baju. Keberagaman ini menunjukkan bahwa mereka mampu memilih. Kemampuan memilih dan mengkomunikasikan pilihan adalah faktor pembentuk determinasi diri.

Kekuatan lain metode ini adalah pada kemampuannya menjembatani komunikasi. Hal ini kami temukan dalam penelitian kami. Foto membantu subyek menemukan cara untuk mengkomunikasikan keinginannya tanpa harus menguasai bahasa yang memang adalah keterbatasan mereka. Masyarakat luas pun dapat mengerti dan menghargai keinginan IBK ketika menyaksikan pameran foto IBK.

Metode participatory photography memerlukan waktu yang lama dan intensitas yang tinggi dalam pengerjaannya. Pemberian perlakuan dalam waktu yang lama ini adalah titik lemah dari metode ini. Efek kelelahan mengganggu berjalannya perlakuan, sehingga efektivitasnya menurun. Hal ini menyebabkan treatment effect melemah. Intensitas eksperimen tidak cukup kuat untuk mengubah determinasi diri yang telah dibentuk dalam waktu yang lama dan kekuatan yang besar. Apalagi saat diketahui ada dekonstruksi determinasi diri dalam diri beberapa subyek. Eksperimen yang dilaksanakan selama dua bulan dengan pemberian perlakuan sebanyak empat pertanyaan ternyata tidak cukup memberi dampak yang signifikan.

Dekonstruksi determinasi diri yang kami temukan pada beberapa subyek, kami kaitkan dengan interdependent construal pada budaya Indonesia. Penelitian sebelumnya yang selama ini menjadi dasar penelitian dan pembuatan teori determinasi diri- berasal dari konteks dan situasi budaya yang berbeda. Menurut teori ekologis Brofenbrenner (Brofenbrenner,1979), perkembangan anak tidak hanya ditentukan oleh self tapi juga oleh semua sistem di luar self, mulai dari microsystem sampai chronosystem. Pada kasus anak di Indonesia, hal ini tidak hanya terjadi dalam arah yang positif dalam hubungannya dengan konstruksinya saja. Namun, hal tersebut juga berpengaruh terhadap stabilitas keberadaan dan dekonstruksinya.

Dalam budaya Indonesia, apabila micrsosystem significant others tidak mendukung self (diri) maka akan terjadi konflik antara diri dan sistem di luar diri. Dalam batas-batas tertentu, konflik ini kami duga akan mendekonstruksi determinasi diri yang sudah dimiliki oleh individu. Hal inilah yang menjelaskan penurunan determinasi diri pada $45 \%$ subyek. Dekonstruksi karena pengaruh sosial ini, belum pernah peneliti temukan dalam literatur tentang determinasi diri, mungkin karena teori determinasi diri ini muncul dari budaya individual yang berbeda dengan subyek penelitian ini yang berada dalam budaya kolektif.

Ketika pertanyaan perlakuan -yang dimaksudkan untuk membantu subyek memahami obyek foto yang harus diambildituliskan, subyek menunjukkan pertanyaan itu kepada orang lain. Kemudian, orang lain tersebut ikut menjadi penentu jawabannya. Hal ini menyebabkan tujuan pemberian perlakuan, yaitu untuk mengetahui keinginan subyek, tidak tercapai. Hal yang terjadi justru subyek merasa dikendalikan oleh orang lain. Sehingga determinasi diri yang diharapkan 
muncul -sebagai akibat subyek mengungkapkan keinginannya- menjadi tidak nampak. Justru yang terjadi adalah sebaliknya, dekonstruksi determinasi diri. Meskipun peneliti telah berusaha menetralkan efek di atas dengan cara menanyai ulang pada saat story telling dan menekankan bahwa keinginan mereka yang penting bukan keinginan orangtua mereka, tapi ternyata efek konflik ini tetap masih terlalu kuat.

\section{Kesimpulan dan Saran}

Penelitian ini penting, bukan hanya bagi IBK, tapi juga bagi semua kelompok masyarakat yang tersingkir atau dianggap sebagai warga negara kelas dua. Penelitian ini sebaiknya dilaksanakan kembali dengan menimbang beberapa hal yang telah ditemukan dalam penelitian ini. Pada pelaksanaan penelitian selanjutnya, penambahan intensitas penelitian seperti penambahan waktu pelaksanaan, penambahan jumlah pertanyaan, pemrosesan lebih dalam, dan pengikutsertaan significant others sebaiknya dilakukan.

Penambahan intensitas penelitian dan jumlah pertanyaan tanpa menambah panjang waktu penelitian- akan mengkibatkan peningkatan efek perlakuan terhadap determinasi diri subyek. Pengembangan pertanyaan terutama berkaitan dengan relasi, ketergantungan opini subyek dengan orang-orang di sekitarnya, dan pilihan tindakan yang bisa dilakukan. Selain itu, perlu juga menambahkan pertanyaan yang berhubungan dengan kesulitan subyek secara sosial. Misalnya, pertanyaan tentang pendapat orang tua mengenai cita-cita subyek dan pandangan orang tua tentang cita-cita yang baik.

Subyek diminta menceritakan pengalaman dan sikap mereka terhadap pelaksanaan kegiatan participatory photography. Subyek yang merasa positif terhadap metode ini mengalami peningkatan determinasi diri. Peningkatan efektivitas metode ini dapat dilakukan dengan cara meningkatkan perasaan positif subyek. Hal ini dapat dilakukan dengan pendampingan subyek lebih dalam sebelum dan ketika mengambil gambar. Sehingga rasa kepemilikan terhadap seluruh proses eksperimen dan hasil foto (cita-cita mereka) lebih dalam. Hal ini akan meningkatkan perasaan positif subyek pada metode ini.

Peningkatan lain yang dapat dilakukan, bila menginginkan efek yang permanen, dapat berupa pengikutsertaan keluarga atau significant others yang ada di sekitar IBK. Significant others harus mendorong individu untuk mencari dan mencapai tujuan personalnya dan bukannya mengikuti atau patuh pada kehendak orang lain. Bila orang-orang di sekitar IBK diikutsertakan, maka keinginan untuk mencapai tujuan personal -yang menjadi dasar determinasi diri- akan menjadi tujuan bersama. Tujuan bersama akan menguatkan determinasi diri pribadi yang berada dalam budaya kolektif. Karena diterima dalam kelompok, apalagi mempunyai tujuan yang menjadi tujuan kelompok sangat bermakna (Matsumoto,2003).

Orang-orang yang berdaya dapat mengambil bagian secara aktif meningkatkan kesejahteraan hidupnya, mendukung keluarga dan lingkungannya menjadi lebih baik, dan memimpin perubahan bagi komunitasnya (National Prevention Strategy, 2011). Mereka juga lebih inovatif, mampu memberi pengaruh yang baik dan inspirasional (Spreitzer, et al. 1999). Mempertimbangkan dampak diatas, pemberdayaan masyarakat sangat penting untuk terus dilakukan. Selain itu, peningkatan kesejahteraan dan pemberdayaan masyarakat adalah tujuan bersama ilmu pengetahuan dan masyarakat pengguna ilmu pengetahuan pada kasus ini kesejahteraan IBK. Maka, pelaksanaan penelitian yang memberdayakan dan meningkatkan kesejahteraan bagi IBK penting untuk dilaksanakan. Baik bagi perkembangan teori ilmu psikologi sendiri, maupun bagi pertimbangan para pengambil keputusan sebagai pengguna aplikasi ilmu psikologi. 


\section{Daftar Pustaka}

Brofenbrenner, U. (1979). The ecology of human development: Experiment by nature and design. Cambridge, MA: Harvard University Press.

Cattaneo, L.B. Chapman, A.R. (2010). The Process of Empowerment. American Psychologist. Vol.65(7): 646-660.

Chung, B. Jones, L. Jones, A. Corbett, C.E. Booker, T. Wells, K.B. Collins, B. (2009). Using Community Arts Events to Enhance Collective Efficacy and Community Engagement toAddress Depression in an African American Community. American Journal of Public Health. 99: 237-244.

Deci, E.L. Ryan, R.M. (1985). Intrinsic Motivation and Self Determination in Human Behavior. New York: Plenum Press.

Dumbrill GC. (2009). Your Policies, Our Children: Messages from Refugee Parents to Child Welfare Workers and Policymakers. Child Welfare, 88 (3): 145-168.

Foster-Fishman, P.G. Law, K.M. Lichty, L.F. Aoun, C. (2010). Youth ReACT for Social Change: A Method for Youth Participatory Action Research. American Journal of Community Psychology, 46: 67-83

Hergenhahn, B.R., Olson, M.H. (1997). An Introduction To Theories of Learning. New Jersey: Prentice Hall.

Hermanto. (2010). Penyelenggaraan pendidikan inklusif membutuhkan keseriusaan manajemen sekolah. Jurnal Pendidikan Khusus., 6 No 1: 65-82

Kamus Besar Bahasa Indonesia. (2011). Jakarta: PT Gramedia Pustaka Utama.Hlm 233, 299, 1502.

Lewis, M.A. Neighbors, C. (2005). SelfDetermination and the Use of Self-
Presentation Strategies. Journal of Social Psychology, 145(4):469-489

Nelson, G. Prilleltensky, I. (2005). Values for Community Psychology dalam Community Psychology. Nelson, G. Prilleltensky, I. (ed.) New York: Palgrave Macmillan.

Nota, L. Ferrari, L. Soresi, S. Wehmeyer, M. (2007). Self-determination, Social Abilities and the Quality of Life of People with Intellectual Disability. Journal of Intellectual Disability Research, 51(part 11): 850-865

Spreitzer GM, Janasz SC, Quinn RE. (1999). Empowered to Lead: The Role of Psychological Empowerment in Leadership. Journal of Organizational Behavior, 20: 511526.

Trainor, A. (2005). Self-Determination Perceptions and Behaviors of Diverse Students with LD During the Transition Planning Process. Journal of Learning Disabilities, 38. Number 3: 233-249

Wehmeyer ML, Shogren KA. (2008). The Self Determination of Adolesence with Intellectual Disability. di dalam Lopez, S.J. (ed.) Positive Psychology, 3: 89-108.

Wehmeyer ML. (1995). The Arc's SelfDetermination Scale: Procedural Guideline

White GW. (2005). Ableism. didalam Nelson G, Prilleltensky I. (ed.) Community Psychology. New York: Palgrave Macmillan.

National Prevention Strategy. Strategic Directions: Empowered People. (2011) Diunduh 29 Mei 2013 dari http://www.surgeongeneral.gov/initia tives/prevention/strategy/empowered people.pdf 